擦係数が大きくなることが分かる。これらの結果から，最 適な摩擦係数と相対変位の関係は直線的な傾向が得られる と思われる。そこで，図 3 で示す直線の傾きと同様に摩擦 力を線形的に変化させてシミュレーション解析を行った.

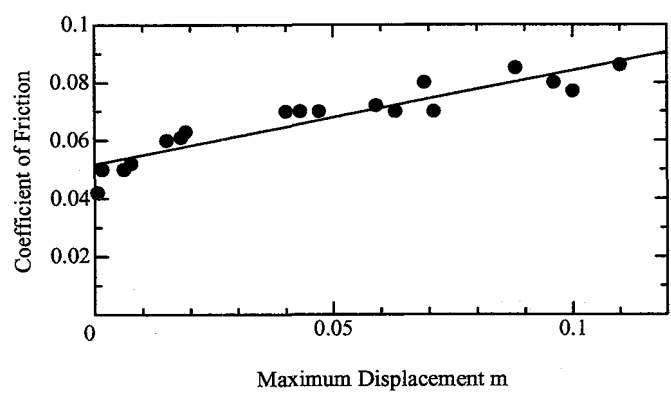

Fig.3 Relation between maximum displacement and coefficient of friction

\section{4. シミュレーション解析}

4.1 解析方法免震装置に生じる相対変位によって摩擦 力を変化させ，シミュレーション解析を行った．はじめに， 困 3 で示す最小二乗法の結果から, 相対変位を $x$, 最適な 摩擦係数を $\mu_{o c}$ とし, 次式が得られた。

$$
\mu_{o c}=\alpha x+\beta \quad \alpha=0.323 \quad \beta=0.052
$$

式(5)を用いて相対変位により摩擦係数を変化させてシミュ レーション解析を行う。ただし, 固有振動数は地震波との 共振を避けることが出来ると考えられる $0.25 \mathrm{~Hz}$ を使用する. また, 静止摩擦係数と動摩擦係数は同じ值とし, 減衰は摩 擦力によるもののみとする。

\section{2 解析結果 実際の地震波を入力加速度として, 前述} の解析方法によりシミュレーション解析を行った. 入力加 速度として, JMA Kobe 波, Ojiya 波, Taft 波の 3 種類を使 用する. 図 4 に入力加速度である JMA Kobe 波形, これに よる答加速度, 相対変位波形を示す. また, 図 5 は JMA Kobe, Ojiya，Taft 波においての応答加速度の最大值, 図 6 は相対変位の最大值を摩擦係数 0.001 に固定して解析を行っ た結果との比較を示している.これらの結果から, 式(5)の 関数を用いて摩擦係数を変化させることで, 相対変位は大 きく低減するが，応答加速度は多少大きくなる，しかし， 入力加速度と比較すると $20 \%$ 以下まで低減している.
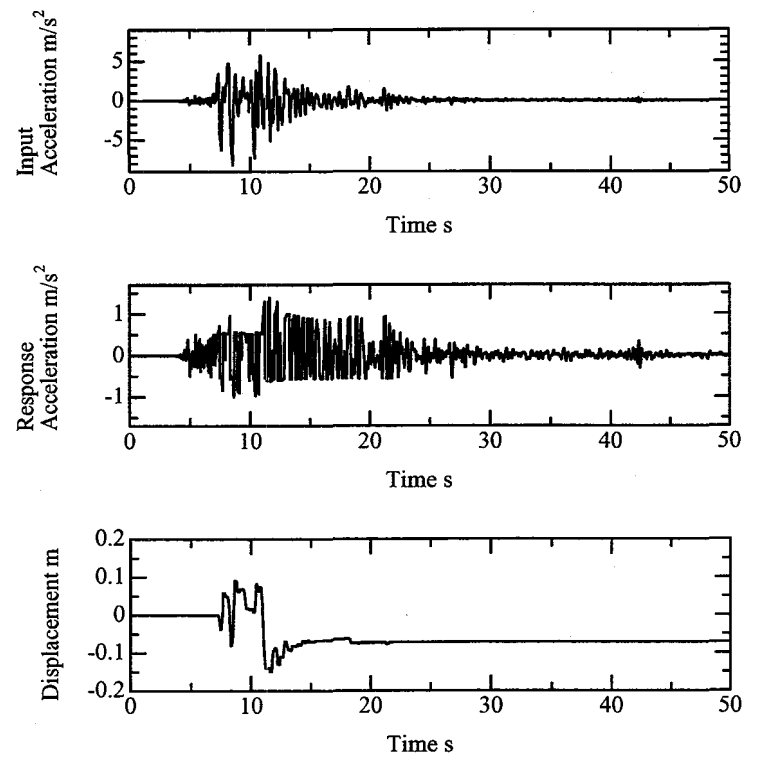

Fig.4 Input and response acceleration and displacement waves of JMA Kobe wave

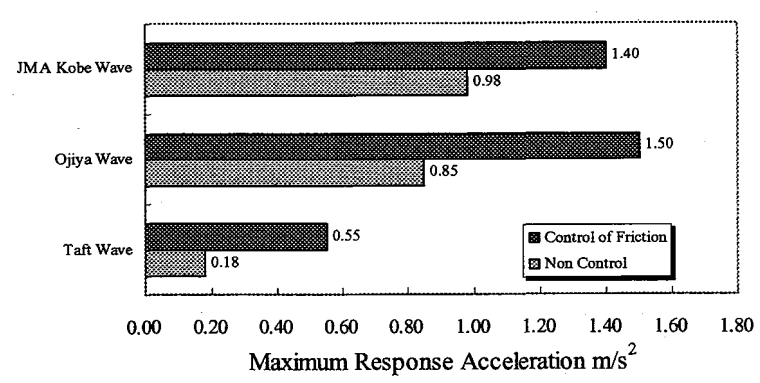

Fig.5 Relation between control of friction and non control

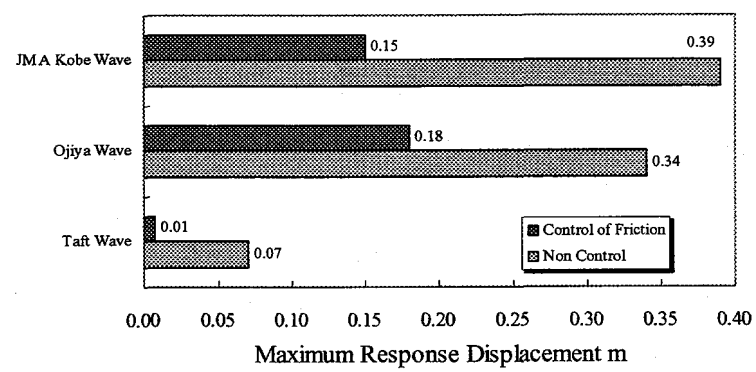

Fig.6 Relation between control of friction and non control

\section{5. 実験}

5.1 実験装置概要解析モデルと同様な条件となる実験 装置の製作を行い，実際の地震波を入力加振して，装置の 応答加速度，相対変位波形を測定する。本実験装置では支 承材として，リニアガイドを用い，復元材として引張ばね を用いる。ここで装置の固有振動数が $0.25 \mathrm{~Hz}$ となる様な柔 らかい引張ばねを使用することで, 応答加速度の低減, ま た, 減衰材として装置下部に摩擦面を設置して相対変位の 低減を実現する。

5.2 摩擦面減衰材として使用する摩擦面は図 7 で示す 様に曲面, 斜面, 平面の 3 個の面によって構成されている. この摩擦面により，装置に生じる相対変位に応じて圧縮ば ねを圧縮して，摩擦力が大きくなる．

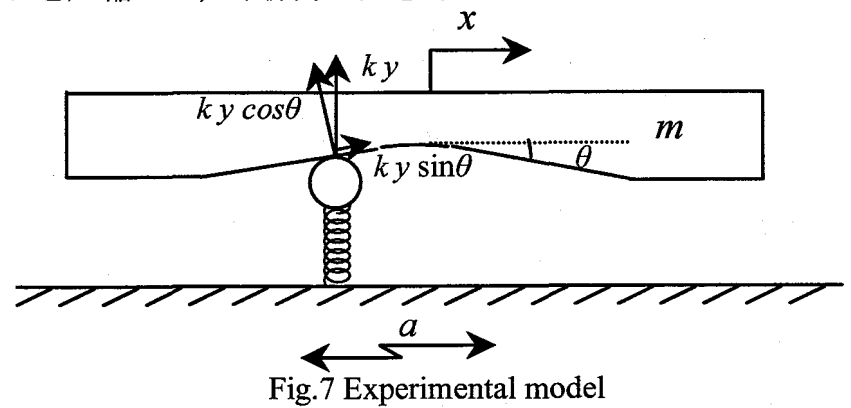

5.3 実験装置のモデル化 以上の実験装置は，下述の式 で表すことができる．また，装置に作用する摩擦力を測定 した結果, 摩摖面の摩擦係数は 0.146 , リニアガイドに働く 摩擦力 $F_{l i}$ は $6.37 \mathrm{~N}$ となった. これらの值と, 式(6)を用いて シミュレーション解析を行い，実験結果と比較する.

$$
\ddot{x}+\omega_{0}^{2} x \pm \frac{k y \sin \theta \cos \theta}{m} \pm \frac{\mu k y \cos ^{2} \theta}{m} \pm \frac{F_{l i}}{m}=-a
$$

\section{6. 結言}

(1) 相対変位が大きく生じる入力加速度の場合, 最適な摩 擦係数も大きくなることが示された。

(2) 相対変位と最適な摩擦係数の関係は直線的な傾向を示 寸.

（3）免震装置に生じる相対変位に応じて摩擦力を変化させ ることで応答加速度と相対変位の両方をある程度まで 低減できると思われる. 